\title{
ANALISIS SISTEM PENGENDALIAN INTERNAL ATAS PEMBIAYAAN MURABAHAH PADA BRI SYARIAH KC MANADO
}

\author{
Ummu Almaas Khoirunnisaa ${ }^{1}$, Hendrik Manossoh ${ }^{2}$, Dhullo Afandi ${ }^{3}$ \\ ${ }^{1,2,3}$ Jurusan Akuntansi, Fakultas Ekonomi dan Bisnis, Universitas Sam Ratulangi, Jl. Kampus Bahu, Manado, \\ 95115, Indonesia \\ E-mail : almaask24@gmail.com
}

\begin{abstract}
Murabaha is a sale and purchase agreement with the selling price of goods at cost plus an agreed profit which the seller must disclose the cost of the goods to the buyer. The purpose of this research is to analyze the internal control system applied to BRI Syariah KC Manado whether it has been effective and in accordance with the principles of COSO (Committee Of Sponsoring Organizations). Data analysis method of this research is using descriptive analysis that compares the results of observations, interviews, document analysis established by the company with existing theory. Data collection methods in this study are interviews, observation, and document review. The results shows that internal controls applied for murabahah financing at BRI Syariah KC Manado include rules set by management, organizational structure, forms and documents used in murabahah financing, recording of legitimate financing transactions, and monitoring of financing. Internal control of murabahah financing at BRI Suyariah KC Manado has been running quite well. But in application still found weaknesses that can hinder the implementation of internal controls in the company. Still found employees who do double job. This is not in accordance with the principle of COSO, where Commitment in the Competence of employees should be improved and more qualified in various areas of specialization. BRI Syariah KC Manado in applying internal controls can be affirmed and in accordance with the principles of COSO.
\end{abstract}

Keywords: COSO, murabahah financing, internal control system.

\section{PENDAHULUAN}

Perbankan di Indonesia menganut dua sistem transaksi yang dikenal dengan bank konvensional dan bank syariah. Seperti halnya bank konvensional, bank syariah juga memiliki produk unggulan yang di tawarkan kepada masyarakat. Salah satu produk bank syariah yang menjadi ketertarikan oleh nasabah adalah produk pembiayaan murabahah. Produk ini menjadi unggulan di bank syariah karena dianggap sebagai alternatif dari sistem kredit bank konvensional yang menggunakan riba (bunga).

Pembiayaan murabahah ini mempunyai nilai yang cukup tinggi dan jumlahnya dari tahun ke tahun terus meningkat, sehingga diperlukan suatu sistem pengendalian intern yang baik agar tidak terjadi kesalahan maupun penyelewengan oleh pihak tertentu. Proses perkembangan suatu usaha sangat bergantung pada sistem yang digunakan. Sistem merupakan sarana yang sangat penting dan bermanfaat bagi perusahaan, karena sistem dapat memberikan informasi kepada manajemen perusahaan agar dapat mengalokasikan berbagai sumber daya perusahaan secara efektif dan efisien.

Sistem yang baik memberikan manfaat dalam memahami lingkungan intern perusahaan. Salah satu sistem yang ada di perusahaan adalah sistem pengendalian intern. Pengendalian internal oleh bank mempunyai arti sangat penting sebagai pengendalian dan pengatur terhadap pembiayaan yang diberikan guna memantau dan mengawasi pembiayaan tersebut. Setiap transaksi pembiayaan yang berkaitan dengan debitur harus dilakukan sesuai dengan prosedur yang ditetapkan. Kesalahan dalam administrasi pembiayaan akan 
menyebabkan informasi keliru dan akhirnya mengakibatkan kesalahan dalam pengambilan keputusan yang dilakukan oleh pihak bank (Ifham, 2010).

BRI Syariah adalah salah satu bank yang melakukan penghimunan dana dari masyarakat dan menyalurkan kembali kepada nasabah dalam bentuk pembiayaan. Adapun kebijakan BRI Syariah KC Manado yang diterapkan untuk menghindari atau meminimalisir terjadinya risiko adalah dengan menerapkan prosedur pemberian kredit dan pengawasan kredit yang melekat pada sistem akuntansi yang ada. Prosedur pemberian kredit berguna untuk memastikan bahwa pemberian kredit oleh bank kepada pihak nasabah telah melewati serangkaian proses atau tahap-tahap pengkajian, penilaian dan penelitian yang seksama sehingga manajemen dalam hal ini diberi kepastian dan dapat berkesimpulan bahwa kredit layak diberikan.

Untuk mengatasi masalah ini diperlukan suatu sistem pengendalian internal yang baik. Sehingga tujuan dari penelitian ini adalah nuntuk menganalisis sistem pengendalian internal yang diterapkan pada BRI Syariah KC Manado apakah telah sesuai dengan prinsip telah sesuai dengan prinsip Committee Of Sponsoring Organizations (COSO).

\section{TINJAUAN PUSTAKA}

\subsection{Konsep Akuntansi}

Akuntansi pada dasarnya akan menghasilkan informasi dari sebuah sistem akuntansi yang ada di dalam sebuah entitas atau organisasi bisnis yang disebut dengan informasi akuntansi yang akan dimanfaatkan oleh pengguna seperti masyarakat umum, masyarakat intelektual (termasuk di dalamnya mahasiswa atau peneliti) dan para pengambil keputusan bisnis dalam organisasi (Pontoh, 2013:2).

\subsection{Akuntansi Keuangan}

Akuntansi keuangan merupakan bidang akuntansi yang menyediakan informasi akuntansi secara umum bagi para pemakai atau pengambil keputusan yang ada diluar organisasi (Pontoh, 2013:2).

\section{3. $\quad$ Sistem Informasi Akuntansi}

Sistem informasi akuntansi menurut Baridwan (2013: 4), sistem informasi akuntansi adalah suatu komponen yang mengumpulkan, menggolongkan, mengolah, menganalisa, dan mengkombinasikan informasi keuangan yang relevan untuk pengambilan keputusan pihakpihak luar (seperti pemerintah, masyarakat, investor, dan kreditor) pihak-pihak dalam (terutama manajemen). menurut Romney Steinbart (2012:24), mengungkapkan sistem adalah sekumpulan dua atau lebih komponen yang saling terkait yang berinteraksi untuk mencapai suatu tujuan.

\subsection{Akuntansi Syariah}

Nurhayati dan Wasilah (2013:2), Akuntansi syariah sangat diperlukan oleh masyarakat islam sebagai yang mendukung agar dapat menerapkan praktik ekonomi Islam dalam tata sosial ekonomi dengan pertimbagan:

1. Konsep kepemilikan yang diyakini oleh orang Islam bahwa harta dan kekayaan adalah milik Allah SWT.

2. Konsep personal accountability yang harus di patuhi oleh Islam. Dengan demikian, dapat disampaikan bahwa cakupan aturan syariah dalam kehidupan begitu luas, termasuk di dalamnya mengenai hukum ekonomi, maka akuntansi syraiah merupakan salah satu bentuk pengalaman dari aturan syariah. Selain itu, Akuntansi Syariah juga berfungsi untuk menguatkan pelaksanaan ekonomi islam/transaksi yang sesuai dengan kaidah Islam melalui pola pengolahan informasi akuntansi yang juga berlandaskan nilai-nilai Islam. 


\subsection{Pembiayaan Murabahah}

Menurut Arwani (2016:119), murabahah adalah transaksi penjualan barang dengan menyatakan harga produk yang dibeli dan menentukan suatu tingkat keuntungan sebagai tambahannya. Murabahah adalah akad jual beli barang dengan harga jual sebesar biaya perolehan ditambah keuntungan yang disepakati dan penjual harus mengungkapkan biaya perolehan barang tersebut kepada pembeli (Rizal yaya dkk, 2014:158).

\subsection{Sistem Pengendalian Internal}

COSO adalah sebuah organisasi swasta yang beranggotakan the American Accounting Association (AAA), AICPA, the Insitute of Internal Auditor (IIA), the Institute of Management Accountants (IMA) dan the Financial Executives Institute (FEI). Organisasi ini pada tahun 1992 mengeluarkan hasil sebuah studi untuk menghasilkan definisi pengendalian intern, yang dikenal dengan model pengendalian intern (Internal Control Model). Produk COSO ini segera diterima secara luas sebagai otoritas pengendalian intern oleh manajemen, akuntan, auditor dan para pemakai laporan keuangan (Krismiaji, 2015:220).

\subsection{Tujuan Pengendalian Internal}

Terdapat beberapa tujuan dari pengendalian internal antara lain (Hery, 2014: 128):

1. Menjaga Aset Perusahaan

2. Tersedianya Informasi Akuntansi yang Handal

3. Mendorong dipatuhinya Kebijakan Manajemen

4. Mendorong Efisiensi

\subsection{Komponen Pengendalian Intern}

Sistem pengendalian intern berkaitan dengan aktivitas operasi suatu organisasi dan ada dengan alasan bisnis yang mendasar. Pengendalian intern akan sangat efektif bila pengendalian tersebut menyatu dengan infastruktur dan merupakan bagian penting bagi suatu organisasi perusahaan. Pengendalian intern yang menyatu mendorong peningkatan kualitas dan inisiatif, menghindari biaya yang tidak seharusnya dan mengahasilkan respon yang cepat terhadap perubahan keadaan (Azhar Susanto, 2013:96). Menurut Diana dan Setiawati (2011:83-92) Lima komponen dalam model pengendalian COSO adalah:

1. Lingkungan Pengendalian

Lingkungan pengendalian suatu perusahaan mencakup seluruh sikap manajemen dan karyawan mengenai pentingnya pengendalian. Lingkungan pengendalian yang lemah kemungkinan besar diikuti dengan kelemahan dalam komponen pengendalian internal yang lain. Lingkungan pengendalian sebagai komponen pengendalian yang pertama, meliputi faktor-faktor sebagai berikut:

a. Filosophi manajemen dan gaya operasi

Manajer harus mengambil tindakan aktif untuk menjadi contoh berperilaku etis dengan bertindak sesuai dengan kode etik personal. Manajer juga harus menekankan pentingnya pengendalian internal.

b. Komitmen terhadap integritas dan nilai-nilai etika

Penting bagi manajemen untuk menciptakan budaya organisasi yang menekankan pada integritas dan nilai-nilai etika. Perilaku etis dan tidak etis manajer dan karyawan berdampak besar terhadap keseluruhan pengendalian internal. Perilaku etis dan tidak etis ini akan menciptakan suasana yang dapat mempengaruhi validitas proses pelaporan keuangan.

c. Komitmen terhadap kompetensi

Penting bagi bagian personalia untuk mengisi lowongan kerja dengan personil yang memiliki pengetahuan dan keterampilan yang sesuai dengan pekerjaan yang harus dikerjakan.

d. Komite Audit dan Dewan Direksi 
Dewan direksi bertanggung jawab untuk memilih komite audit yang beranggotakan orang-orang dari luar perusahaan. Peran komite audit adalah memantau akuntansi perusahaan serta praktik dan kebijakan pelaporan keuangan. Komite audit juga berperan sebagai perantara antara auditor internal dan auditor eksternal.

e. Struktur organisasi

Struktur organisasi perusahaan menggambarkan pembagian otoritas dan tanggung jawab dalam perusahaan dalam rangka mencapai tujuan perusahaan. Struktur organisasi ini harus disajikan secara ekplisit dalam bentuk grafis agar jelas siapa bertanggung jawab atas apa.

f. Penetapan otoritas dan tanggung jawab

Otoritas adalah hak yang dimiliki karena posisi formal seseorang untuk memberi perintah kepada bawahan. Tanggung jawab adalah kewajiban seseorang untuk menjalankan tugas tertentu dan untuk diminta pertanggung jawabannya atas hasil yang dicapai.

g. Kebijakan dan praktik sumber daya manusia

Kegiatan sumber daya manusia meliputi perekrutan karyawan baru, orientasi karyawan baru, pelatihan karyawan, motivasi karyawan, evaluasi karyawan, promosi karyawan, kompensasi karyawan, konseling karyawan, perlindungan karyawan dan pemberhentian karyawan.

2. Aktivitas Pengendalian

Aktivitas pengendalian yang terkait dengan pelaporan keuangan antara lain meliputi:

a. Desain dokumen yang baik dan bernomor urut cetak

Desain dokumen baik adalah desain dokumen yang sederhana sehingga meminimalkan kemungkinan kesalahan mengisi. Dokumen juga harus memuat tempat untuk tanda tangan bagi mereka yang berwenang untuk mengotorisasi transaksi. Dokumen juga perlu bernomor urut tercetak sebagai wujud pertanggung jawaban penggunan dokumen.

b. Pemisahan tugas

Ada tiga pekerjaan yang harus dipisahkan agar karyawan tidak memiliiki kesempatan untuk mencuri aset perusahaan dan memalsukan catatan akuntansi. Ketiga pekerjaan tersebut diantaranya fungsi penyimpanan harta contoh pemegang persediaan yang berwenang untuk mengisi buku cek, fungsi pencatat dan fungsi otorisasi transaksi bisnis.

c. Otorisasi yang memadai atas setiap transaksi bisnis

Otorisasi adalah pemberian wewenang dari manajer kepada bawahannya untuk melakukan aktivitas atau untuk mengambil keputusan tertentu.

d. Mengamankan harta dan catatan perusahaan

Harta perusahaan meliputi kas, persediaan, peralatan dan bahkan data dan informasi perusahaan. Bentuk pengamanan tersebut seperti menciptakan pengawasan yang memadai.

e. Menciptakan adanya pengecekan independen atas pekerjaan karyawan lain

Pengecekan independen ini meliput membandingkan catatan dengan aktual fisik.

\section{Penaksiran Risiko}

Organisasi harus menyadari dan waspada terhadap berbagai resiko yang dihadapinya. Organisasi harus pula menetapkan mekanisme untuk mengidentifikasi, menganalisis dan mengelola resiko-resiko terkait.

4. Informasi dan Komunikasi 
Informasi harus diidentifikasi, diproses dan dikomunikasikan ke personil yang tepat sehingga setiap orang dalam perusahaan dapat melaksanakan tanggung jawab mereka dengan baik.

5. Pengawasan Kinerja

Kegiatan dalam pegawasan kinerja diantaranya, supervisi yang efektif, akuntansi pertanggungjawaban dan pengauditan internal.

\subsection{Penelitian terdahulu}

Penelitian terdahulu yang penulis jadikan sebagai bahan pertimbangan dalam melakukan penelitian di Bank BRI Syariah KC Manado. Penelitian yang dilakukan oleh Zakaria (2015), tentang Evaluasi Pengendalian Internal Pembiayaan Murabahah pada BMT Sidogiri. Hasil penelitiannya menunjukkan pengendalian internal terhadap pembiyaan murabahah pada BMT Sidogiri Cabang Pembantu Kaliwates sudah berjalan dengan cukup baik. Namun, dalam praktiknya masih ditemukan beberapa kelemahan yang dapat menghambat pelaksanaan.

\section{METODE PENELITIAN}

\subsection{Jenis Penelitian}

Penelitian ini termasuk pada jenis penelitian kualitatif deskriptif. Jenis penelitian yang digunakan adalah penelitian deskriptif kualitatif. Penelitian deskriptif kualitatif meliputi pengumpulan data untuk diuji atau menjawab pertanyaan mengenai status terakhir dari subjek penelitian Deskriptif kualitatif yaitu penelitian yang dilakukan untuk mengetahui nilai variabel mandiri, baik satu variable atau lebih dan tidak terdapat perbandingan atau menghubungkan dengan variabel lain, yang datanya dinyatakan dalam bentuk verbal dan dianalisis tanpa meggunakan teknik statistik (Kuncoro, 2013:12). Dalam penelitian ini, peneliti akan menganalisis dan membandingkan perbandingan antara sistem pengendalian internal pada BRI Syariah KC Manaado dengan teori prinsip-prinsip standar yang berlaku.

\subsection{Waktu dan Tempat Penelitian}

Dalam penelitian ini, penulis memilih lokasi di BRI Syariah KC Manado sebagai tempat penelitian. Dengan melihat lamanya waktu yang akan digunakan penulis untuk meneliti adalah 2 (dua) bulan.

\subsection{Prosedur Penelitian}

Langkah-langkah yang telah dilakukan pada pelaksanaan penelitian sebagai berikut:

1. Mengajukan permohonan pada pihak yang berwenang untuk menjadikan BRI

Syariah KC Manado sebagai tempat objek penelitian.

2. Melakukan wawancara kepada Bapak Ari selaku pihak Administrasi keuangan BRI Syariah KC Manado yang bertanggung jawab terhadap pembiayaan murabahah.

3. Mengumpulkan informasi mengenai gambaran umum perusahaan dan mengenai sistem pengendalian internal pembiayaan muarabahah pada BRI Syariah KC Manado.

4. Analisis data yang diperoleh dengan menggunakan analisis deskriptif yang bertujuan untuk mengetahui sistem pengendalian internal terhadap pembiayaan murabahah BRI Syariah KC Manado yang disesuaikan berdasarkan teori prinsip COSO.

\subsection{Metode Analisis}

Metode analisis data yang digunakan atau diterapkan untuk menganalisis dalam penelitian ini adalah metode analisis deskriptif yaitu metode yang dilakukan dengan cara menguraikan, menggambarkan, membandingkan, dan menerangkan suatu keadaan yang bertujuan untuk mendapatkan gambaran yang jelas dan terperinci mengenai suatu keadaan berdasarkan data atau informasi yang telah didapatkan, kemudian mengambil kesimpulan dan selanjutnya memberikan saran dari hasil perbandingan tersebut. 


\section{HASIL PENELITIAN DAN PEMBAHASAN}

\subsection{Hasil penelitian}

\subsubsection{Pembiyaan Murabahah di Bank BRI Syariah KC Manado}

BRI Syariah Manado sebagai penjual di dalam praktek pembiayaan murabahahnya menerapkan metode pesanan mengikat, sehingga nasabah tidak dapat membatalkan pesanannya. Bank memberikan pilihan kepada nasabah apakah ingin membeli sendiri barangnya atau yang biasa disebut dengan mewakilkan pembelian kepada nasabah dan harus menggunakan akad wakalah. Berdasarkan hasil wawancara yang peneliti lakukan kepada Bapak Arianto selaku bagian administrasi keuangan dapat diketahui bahwa BRI Syariah KC Manado menggunakan metode pesanan mengikat karena bank menghindari resiko kerusakan, tidak adanya wilayah untuk menyimpan barang persediaan, dan ketidaksesuaian spesifikasi barang dari nasabah.

Setelah itu, BRI Syariah yang telah menerima data diri nasabah dan data barang pesanan akan diproses lebih lanjut, dalam menjalankan pembiayaan murabahah BRI Syariah KC Manado menjual barang dengan menegaskan harga perolehan barang kepada nasabah dengan jujur dan nasabah akan membayar dengan harga lebih tinggi sebagai keuntungan (margin) bagi BRI Syariah KC Manado selaku penjual sesuai dengan kesepakatan antara pihak bank dan nasabah. Ketentuan ini sudah diinformasikan kepada nasabah sebelum melakukan transaksi murabahah.

\subsubsection{Analisis Pengendalian Internal Atas Pembiayaan Murabahah Pada BRI Syariah \\ K.C Manado}

\section{Lingkungan Pengendalian}

Lingkungan pengendalian adalah komponen pertama dari lima komponen pengendalian internal. Ada tujuh unsur penilaian dalam komponen ini yaitu: filosofi manajemen dan gaya operasi, komitmen terhadap integritas dan nilai etika, komitmen terhadap kompeten, komite audit dan dewan direksi, struktur organisasi, penetapan otoritas dan tanggung jawab, kebijakan dan praktik sumber daya.

Setelah melakukan wawancara dengan Bapak Arianto selaku bagian administrasi keuangan tentang lingkungan pengendalian dijelaskan bahwa semua faktor dalam lingkungan pengendalian pada Bank BRI Syariah sudah cukup memadai seperti struktur organisasi sudah berjalan secara fungsional karena menunjukkan garis-garis wewenang dan tanggung jawab yang jelas dalam aktivitas operasional dan telah memenuhi pengawasan yang baik dalam perusahaan.

\section{Aktivitas Pengendalian}

Aktivitas pengendalian BRI Syariah KC Manado meliputi adanya kebijakan dan prosedur-prosedur yang dijalankan dalam perusahaan yang dapat menjamin sistem tersebut telah berjalan efektif. Aktivitas pengendalian yang dilaksanakan BRI Syariah KC Manado terdiri dari:

a. Desain dokumen yang baik dan bernomor urut cetak

Dokumen yang berada di BRI Syariah KC Manado sudah memiliki dokumen dengan nomor urut tercetak. Dokumen tersebut diantaranya: copy KTP pemohon dan KTP pasangan, copy kartu keluarga, copy surat nikah, NPWP pribadi, SP3, surat keterangan pekerjaaan, surat keterangan penghasilan/slip gaji, copy surat pemesanan rumah, surat peryataan nasabah.

b. Pemisahan tugas

Otorisasi penyetujuan pemberian pembiayaan murabahah pada BRI Syariah KC Manado telah terpisah tugas dan wewenangnya dengan fungsi analisis pembiayaan. Kepala Cabang yang memiliki wewenang menyetujui pemberian 
pembiayaan sesuai dengan batasan nominal yang dimilki terpisah dari fungsi analisis pembiayaan yang dilakukan oleh account officer (AO).

c. Otorisasi transaksi

Pelaksanaan perjanjian kredit dilakukan dengan penandatanganan akad pembiayaan oleh debitur, notaris publik (sebagai saksi), dan diotorisasi oleh Kepala Cabang, serta disaksikan pihak-pihak yang berkepentingan sudah cukup jelas menggambarkan persetujuan para pihak yang dituangkan dalam perjanjian sesuai syariah Islam dan hukum.

d. Mengamankan harta dan catatan perusahaan

BRI Syariah KC Manado sudah memiliki pengendalian fisik yang sangat baik dalam pelaksanaan pemrosesan pembiayaan murabahah. Hal ini ditunjukkan dengan ruang lemari besi yang tertutup rapat dan merupakan ruang terbatas, kunci dengan menggunakan sistem dual control yang terdiri dari dua pintu yaitu besi (solid) yang mempunyai kode rahasia sekaligus kunci biasa serta pintu besi dengan kunci tersendiri.

e. Menciptakan adanya pengecekan independen

Pemerikasaan internal pada BRI Syariah KC Manado berfungsi untuk memastikan bahwa seluruh transaksi diproses secara akurat. Pemeriksaan ini dilakukan secara independen, agar pemeriksaan berjalan efektif. Review kinerja dilakukan secara rutin setiap harinya melalui laporan dan observasi, selain itu juga setiap bulannya agar perusahaan dapat menilai apakah tujuan atau target

\section{3.} yang telah ditetapkan sudah mencapai target atau belum.

\section{Penaksiran Resiko}

Penaksiran resiko adalah proses mengidentifikasi dan menganalisis resiko-resiko yang relevan dalam pencapaian tujuan perusahaan. Penilaian resiko sangat di perlukan untuk menunjang efektifitas kinerja dari suatu perusahaan. Dalam hal ini, BRI Syariah KC Manado memperkirakan resiko atau kendala yang akan timbul untuk mengidentifikasi, manganalisis dan mengelola risiko yang berhubungan dengan pengendalian internal.

\section{Informasi dan Komunikasi}

Perusahaan telah mendapat sistem akuntansi yang cukup memadai dengan adanya prosedur-prosedur yang memperlihatkan bagaimana transaksi yang terjadi dilaksanakan. Dengan adanya prosedur tersebut cukup membuktikan adanya informasi tertulis.

\section{Pengawasan Kinerja}

Pemantauan juga dilakukan untuk melihat proses pembiayaan yang telah dilakukan sudah sesuai atau belum dengan prosedur dan kebijakan yang ditetapkan oleh BRI Syariah KC Manado. Pemantauan ini dilakukan oleh pimpinan cabang dan auditor internal BRI Syariah. Selain itu, pengawasan terhadap semua jenis pembiayaan termasuk kepada pihakpihak yang terkait dengan Bank BRI Syariah dan debitur-debitur besar tertentu, dimana kepada mereka ini harus dilakukan lebih intensif.

\subsection{Pembahasan}

4.2.1. Pengendalian Internal Atas Pembiayaan Murabahah pada BRI Syariah KC Manado Berdasarkan Komponen COSO

\subsubsection{Lingkungan Pengendalian Pembiayaan Murabahah pada BRI Syariah KC Manado}

1. Filosofi manajemen dan gaya operasi

Berdasarkan hasil penelitian menurut bagian personalia, filosofi manajemen yang diterapkan manajer BRI Syariah KC Manado sudah sesuai dengan prinsip COSO. Pada hal ini pimpinan BRI Syariah KC Manado menekankan pada karyawan untuk selalu mematuhi tata tertib yang dibuat oleh perusahaan. Seluruh karyawan ditekankan untuk bertindak serta bersikap baik kepada semua debitur, karyawan serta pihak-pihak lain 
yang berhubungan dengan perusahaan. Selain itu BRI Syariah KC Manado senantiasa berusaha memberikan pelayanan yang memuaskan kepada nasabah dengan cara sebisa mungkin berusaha memberika pelayanan sesuai dengan prinsip syariah.

2. Komitmen terhadap integritas dan nilai-nilai etika

Penting bagi manajer untuk menciptakan budaya organisasi yang menekankan pada integritas dan nilai-nilai etika. BRI Syariah KC Manado telah menerapkan integritas dan nilai etis pada karyawan. Menurut bagian personalia, integritas dan nilai etika yang ada di Bank BRI Syariah Manado menjunjung tinggi kejujuran dalam setiap kegiatan. Kejujuran yang dimaksud adalah sikap disiplin yang berintegritas tinggi. Kejujuran merupakan salah satu etika yang dipelihara pada Bank BRI Syariah KC Manado.

3. Komitmen terhadap kompetensi

Perusahaan dalam melaksanakan perekrutan karyawan ditangani oleh bagian personalia dan diputuskan langsung oleh direktur. Pada BRI Syariah KC Manado dalam melaksanakan perekrutan perusahaan mengharuskan pendidikan minimal Sarjana 1 untuk staf kantor. Dan bank tidak melihat latar belakang jurusan pendidikan dengan bagian pekerjaan yang ada di perusahaan. Komitmen terhadap kompetensi yang diterapakan pada BRI Syariah KC Manado sudah baik. Namun, seharusnya bank melakukan perekrutan karyawan sesuai dengan jurusan pendidikannya atau yang mengerti tentang dunia perbankan.

4. Komite audit dan dewan direksi

Faktor yang dapat mempengaruhi efektivitas dari komite audit dan dewan komisaris meliputi kemandirian (independency) terhadap pihak manajemen dan seberapa jauh keterlibatannya dalam aktivitas manajemen. Dewan komisaris Bank BRI Syariah terdiri dari dua orang yang secara formal telah dibentuk Satuan Kerja Audit Intern (SKAI).

5. Struktur organisasi

Struktur organisasi yang terdapat pada BRI Syariah KC Manado sudah cukup baik, yaitu terdiri dari kepala pimpinan cabang yang dibawahnya terdiri dari bagian keuangan, bagian administrasi, operasional. Struktur organisasi ini telah memperlihatkan dengan jelas pembagian tugas dan wewenang dari setiap fungsi yang ada, sehingga pengendalian dapat dilakukan dengan lebih baik.

6. Penetapan otoritas dan tanggung jawab

Pemisahaan fungsi pada struktur organisasi di Bank BRI Syariah KC Manado juga telah diadakan, yaitu fungsi keuangan, administrasi, operasional, personalia, dan fungsi analisis. Namun, dalam penetapan otoritas dan tanggung jawab pada BRI Syariah KC Manado belum begitu baik. Hal ini karena adanya perangkapan fungsi seperti dalam fungsi operasional yang bisa merangkap sebagai teller. Hal tersebut dapat menyebabkan tidak maksimalnya pengendalian intern yang dilaksanakan oleh bank.

7. Kebijakan dan praktik sumber daya manusia

Kebijakan dan praktik sumber daya manusia yang diterapkan pada BRI Syariah KC Manado sudah berjalan dengan baik. Ini dapat dibuktikan dengan adanya pedoman tentang pemberian pembiayaan sebagai petunjuk teknis dalam pelaksanaan pemberian pembiayaan, pemberian Job Training bagi karyawan baru maupun lama, pemberian reward dan punishment juga dilakukan Bank BRI Syariah Manado kepada karyawan yang berprestasi sebagai bentuk penghargaan dari perusahaan atas pencapaian target dan kinerja yang baik. Biasanya bentuk reward yang diberikan berupa kenaikan jabatan dan bonus gaji. Sejauh ini karyawan bank belum pernah mendapatkan punishment.

\subsubsection{Aktivitas Pengendalian Pembiayaan Murabahah pada BRI Syariah KC Manado}

1. Desain dokumen yang baik dan bernomor urut cetak

Desain dokumen yang digunakan dalam prosedur pembiayaan murabahah telah bernomor urut tercetak hal ini merupakan alat untuk memberikan otorisasi terlaksananya 
transaksi sehingga dengan penggunaan nomor urut tercetak akan dapat menetapkan pertanggungjawaban terlaksananya transaksi dokumen yang baik dan bernomor urut cetak.

2. Pemisahan tugas

Otorisasi penyetujuan pemberian pembiayaan murabahah pada BRI Syariah KC Manado telah terpisah tugas dan wewenangnya dengan fungsi analisis pembiayaan. Kepala Cabang yang memiliki wewenang menyetujui pemberian pembiayaan sesuai dengan batasan nominal yang dimilki terpisah dari fungsi analisis pembiayaan yang dilakukan oleh account officer (AO). Hasil analisis pembiayaan dari adanya pemisahan tugas yang menjadi pertimbangan pengambilan keputusan pembiayaan murabahah dapat memberikan dasar yang memadai untuk mengevaluasi hasil kinerja masing-masing karyawan.

3. Otorisasi transaksi

Semua tahapan dan prosedur dalam pengajuan permohonan pembiayaan merupakan tanggung jawab dari setiap karyawan pembiayaan yang terkait dan sudah menjadi tugas dan wewenangnya masing-masing. Pengendalian otorisasi pemberian pembiayaan telah berjalan dengan baik. Hal ini dapat dilihat dengan adanya batasan limit, para pejabat tidak akan kehilangan otoritas dan kewenangannya selama proses pembiayaan berlangsung. Penandatangan akad yang harus dilakukan oleh pejabat yang memberikan persetujuan pembiayaan akan memperjelas kewenangan masing-masing pejabat.

4. Mengamankan harta dan catatan perusahaan

Pelaksanaan pengamanan harta dan catatan perusahaan sudah baik. Pada BRI Syariah KC Manado tersedia gudang sebagai tempat penyimpanan dan dikunci oleh pegawai yang berwenang setelah jam kerja selesai. Perlindungan fisik terhadap dokumen dan catatan pun sudah memadai yaitu dengan tersedianya map sebagai tempat penyimpanan dokumen lalu dimasukkan ke dalam lemari besi dan hanya bagian yang berwenanglah yang dapat mengaksesnya. Dan di setiap ruangan kerja terdapat CCTV di dalamnya.

5. Menciptakan adanya pengecekan independen

Pengecekan dilakukan agar dalam setiap kegiatan di dalam perusahaan apabila terdapat kesalahan dapat dengan mudah terdeteksi dan segera diperbaiki. Pengecekan yang dilakukan pada Bank BRI Syariah KC Manado sudah cukup baik hal ini terlihat dari adanya analisis oleh setiap kepala bagian atas laporan yang diberikan oleh karyawan di tiap bagiannya. Pemeriksaan independen atas pelaksanaan dalam prosedur analisis dan evaluasi pembiayaan dilakukan oleh pejabat Account Development Program. Hasil analisis pembiayaan yang dilakukan oleh ADP (Account Pevelopment Program) dievaluasi kembali dan akan diputuskan oleh Pinca (Pimpinan Cabang).

\subsubsection{Penaksiran Resiko Pembiayaan Murabahah pada BRI Syariah KC Manado}

Penaksiran resiko yang dilakukan oleh BRI Syariah KC Manado sudah cukup baik. Tindakan yang dilakukan oleh BRI Syariah KC Manado dalam mengidentifikasi, menganalisis, dan menilai adanya risiko yang muncul dalam perusahaan yaitu, direksi dan pejabat mengadakan rapat umum untuk membahas risiko-risiko yang muncul dalam pencapaian tujuan perusahaan. Perusahaan sudah cukup tanggap terhadap resiko-resiko yang telah ditentukan dan perubahan-perubahan yang harus dilakukan untuk bisa bersaing di era globalisasi ini, baik dari segi peraturan dan standar baru yang harus diikuti.

\subsubsection{Informasi dan Komunikasi Pembiayaan Murabahah pada BRI Syariah KC Manado}

Informasi dan komunikasi yang ada pada BRI Syariah KC Manado sudah cukup baik hal ini dilihat pada saat pelaksanaan proses analisis pembiayaan, BRI Syariah KC Manado memperoleh informasi mengenai calon nasabah melalui wawancara langsung, serta 
pengumpulan informasi melalui lingkungan sekitar seperti tetangga, rekan kerja calon nasabah, dan pihak lain.

\subsubsection{Pengawasan Kinerja Pembiayaan Murabahah pada BRI Syariah KC Manado}

Pengawasan kinerja yang ada pada BRI Syariah KC Manado sudah baik. Bank telah melakukan pengawasan sepanjang waktu dengan cara memantau transaksi atas pembiayaan nasabah secara berkala. Selain itu, BRI Syariah KC Manado juga memantau kinerja karyawannya. Pemberian fasilitas atau reward kepada karyawan yang memiliki kinerja yang baik terhadap perusahaan merupakan usaha yang dilakukan oleh BRI Syariah KC Manado untuk meningkatkan motivasi karyawan.

\section{KESIMPULAN DAN SARAN}

\subsection{Kesimpulan}

Berdasarkan hasil penelitian dan pembahasan yang dilakukan oleh peneliti mengenai analisis pengendalian internal atas pembiayaan murabahah berdasarkan prinsip COSO yang telah dilakukan di BRI Syariah Kantor Cabang Manado, maka diperoleh beberapa kesimpulan sebagai berikut:

1. Pengendalian internal yang diterapkan untuk pembiayaan murabahah di BRI Syariah KC Manado meliputi aturan yang ditetapkan oleh manajemen, struktur organisasi, formulir dan dokumen yang digunakan dalam pembiayaan murabahah, pencatatan transaksi pembiayaan yang sah, serta pengawasan terhadap pembiayaan. Pengendalian internal terhadap pembiayaan murabahah pada BRI Syariah KC Manado sudah berjalan dengan cukup baik. Namun dalam praktiknya masih ditemukan kelemahan yang dapat menghambat pelaksanaan pengendalian internal.

2. Masih ditemukan karyawan yang melakukan rangkap kerja atau merangkap dua bagian. Hal ini tidak sesuai dengan prinsip COSO, dimana penetapan otoritas dan tanggung jawab dan pemisahan tugas harus lebih ditingkatkan dan lebih berkualitas dalam berbagai bidang spesialisasi. Dengan adanya pemisahan tugas dan wewenang yang jelas membuat para karyawan memiliki rasa tanggung jawab terhadap kewajiban masing-masing. Apabila dalam praktiknya masih sering ditemui karyawan yang melakukan pekerjaan ganda, kemungkinan terjadi kesalahan dan kelalaian dalam bidangnya akan sangat mungkin terjadi.

\subsection{Saran}

Berdasarkan kesimpulan dari penelitian ini, maka saran yang dapat diberikan peneliti adalah sebagai berikut:

1. Sebaiknya bank BRI Syariah KC Manado dalam menerapkan pengendalian internal dapat mempertegas dan sesuai dengan prinsip COSO (Committee Of Sponsoring Organizations), sehingga bank BRI Syariah KC Manado dalam menjalankan praktik pembiayaan murabahah mempunyai sistem pengendalian internal yang lebih lebih efektif dan tindakan ini merupakan salah satu upaya bank untuk mengurangi resiko kredit macet.

2. Dalam meningkatkan efektifitas kerja dari setiap bagian fungsi tugas, bank BRI Syariah KC Manado sebaiknya perlu menambah jumlah karyawan untuk pemisahan fungsi yang lebih efektif agar dapat meringankan kinerja setiap bagian fungsi, serta untuk menghindari terjadinya personil yang memegang fungsi ganda. Selain itu juga untuk meningkatkan efektifitas sistem pengendalian intern sehingga dapat memperkecil resiko dan penyelewengan yang mungkin terjadi. 


\section{DAFTAR PUSTAKA}

Arwani, Agus. (2016). Akuntansi Perbankan Syariah: dari Teori ke Praktik (Adopsi IFRS).

Edisi 1 Cetakan 1. Yogyakarta: Deepublish.

Azhar, Susanto. (2013). Sistem Informasi Akuntansi. Bandung: Lingga Jaya.

Baridwan, Zaki, 2013. Sistem Informasi Akuntansi. Edisi Kedua. Salemba Empat. Jakarta.

Diana, Anastasia dan Setiawati Lilis. (2011). Sistem Informasi Akuntansi, Perancangan, Prosedur dan Penerapan. Edisi 1. Yogyakarta: Andi Yogyakarta.

Hery. (2014). Pengendalian Akuntansi dan Manajemen. Kencana: Jakarta.

Ifham, Sholihin Ahmad. (2010). Buku Pintar Ekonomi Syariah, Gramedia Pustaka Utama. Jakarta.

Kasmir. (2014). Bank dan Lembaga Keuangan Lainnya. Edisi Revisi 2014. Jakarta: Raja Grafindo Persada.

Krismiaji. (2015). Sistem Informasi Akuntansi. Yogyakarta: UPP STIM YKPN.

Kuncoro, Mudrajad. (2013). Metode Riset Untuk Bisnis \& Ekonomi. Edisi 4. Penerbit Erlangga. Jakarta.

Pontoh, Winston. (2013). Akuntansi Konsep dan Aplikasi. Halaman Moeka. Jakarta.

Rizal yaya, Aji Erlangga Martawireja, dan Ahim Abdurahim. (2014). Akuntansi Perbankan Syariah. Edisi II. Salemba Empat. Jakarta.

Romney, Marshall, Steinbart. (2015). Accounting Information Systems. $13^{\text {th }}$ Edition. Upper Saddle River, New Jersey: Pearson Education Inc.

Zakaria, Nabila Shyavira (2015). "Evaluasi Pengendalian Internal Pembiayaan Murabahah pada BMT Sidogiri”. Universitas Jember (UNEJ). Jurnal Vol 1 (1): 1-6. 